\title{
The Effect of an LGBTQ Themed Literary Instructional Unit on Adolescents' Homophobia
}

\author{
Victor MALO-JUVERA \\ University OF NORTh CAROLINA WiLmington
}

Numerous scholarly works extol the use of LGBTQ themed literature as part of English language arts instruction with the implication that its use may improve the school climate for LGBTQ students; however, there is a dearth of research that empirically examines whether or not this type of instruction measurably impacts adolescents' homophobia. To address this paucity, this study examined the ability of a dialogically organized, reader response-based instructional unit of the young adult novel Geography Club to reduce adolescents' homophobia. A quasi-experimental design was used with eighth grade students in seven English language arts classes. Homophobia was measured using a researcher-created scale. Analysis of pretests revealed that girls had lower levels of homophobia than boys and that Black students had higher levels of homophobia than Hispanic students. Posttest results indicated that the intervention was successful in lowering homophobia. Exploratory factor analysis revealed a three factor solution: Interpersonal Homophobia, Attitudes toward Homophobia, and Sexuality as a Choice. Post-hoc tests revealed differing effect sizes for the aforementioned factors and showed that there was no backlash to treatment in participants with high pretest homophobia. This paper argues that schools and teacher education programs should make a serious effort to incorporate LGBTQ themed texts into curricula as part of a concerted effort to reduce the culture of homophobic violence that has become institutionalized in many schools.

In recent years there has been a growth of publications that detail the use of LGBTQ (Lesbian, Gay, Bisexual, Transgender, Questioning/Queer) themed literature and curricula in English language arts. In 2009, Lindbloom edited a special themed issue of English Journal titled "Sexual Identity and Gender Variance" that addressed various LGBTQ issues in English education and almost every journal in the field of English language arts has published articles that address LGBTQ themed literature and/or issues. The majority of these are descriptions of LGBTQ themed curricula (e.g., Sieben \& Wallowitz, 2009); however, an underlying assumption of this body of scholarship is that 
the use of these materials will lead to greater acceptance of all people regardless of their sexual orientation, and therefore a concomitant reduction in homophobia. Unfortunately, there is little published empirical research that has used quantitative measures to support these claims. This study addressed this dearth by using a pretest-posttest control group design to offer a rigorous empirical examination of the effect that classroom instruction of LGBTQ themed literature had on adolescents' homophobia.

\section{BACKGROUND}

Bullying is pandemic in schools and is characterized by repeated attacks and intimidation of a student on his/her way to school or at school and may use physical, verbal, or relational force (Espelage, Basile, \& Hamburger, 2011; Espelage, Holt, \& Henkel, 2003; Olweus, 1993). The Youth Risk Behavior Surveillance (Kann et al., 2013) reported that 20.1\% of students have been victimized by some form of bullying at school; middle school has been identified as a place for increased bullying with $24.2 \%$ of students reporting having been bullied and $8.4 \%$ reporting being bullied at least once per week (Nansel, Overpeck, Pilla, Ruan, Simons-Morton, \& Scheidt, 2001). A frequent form of bullying is homophobic bullying, which is bullying that is directed toward individuals who are or who are perceived to be gay, lesbian, bisexual, transgender, or questioning (Prati, 2012). Homophobic bullying is rooted in homophobia, which is a broad term that has been defined as a negative attitude, belief, reaction, or action toward homosexuals that is similar to prejudices such as racism and sexism (Bernat, Calhoun, Adams \& Zeichner, 2001; Herek, 2000).

Homophobia is often manifested in homophobic language which is ubiquitous in schools; $84.9 \%$ of students have heard "gay" used in a negative connotation and $71.3 \%$ have heard other homophobic remarks (Kosciw, Greytak, Bartkiewicz, Boesen, \& Palmer, 2012). Specific words and phrases such as "faggot," "dyke," or "that's so gay" are so rife in schools that $75 \%$ of students in Massachusetts schools without Gay-Straight Alliances reported hearing them on a daily basis (Szalacha, 2003). Beyond being part of the institutionalized lexicon at many schools, the use of directed homophobic epithets is the most frequent form of homophobic bullying and researchers have found that $26 \%$ of all boys who were bullied were called "gay" (Rivers, 2001); moreover, these victims experienced greater psychological distress than boys who were bullied without homophobic epithets (Swearer, Turner, Givens, \& Pollack, 2008). Although homophobic bullying can be directed at students who identify as heterosexual, LGBTQ students are most often the targets of 
homophobic bullying as $81.9 \%$ have been verbally harassed, $38.3 \%$ have been physically harassed, and $18.3 \%$ have been physically assaulted in school (Kosciw et. al., 2012). Being victimized by homophobic bullying has been correlated with elevated risk for depression, absenteeism, and drug use (Bontempo \& D’Augelli, 2002). Perhaps most distressing, 1 in 3 LGBTQ high school students reported attempting suicide at least once (Robin, Brener, Donahue, Hack, Hale, \& Goodenow, 2002). This is directly related to bullying as LGBTQ victims of homophobic bullying attempt suicide at 3 to 4 times the rate of their non-victimized heterosexual peers (Bontempo \& D'Augelli, 2002; Rotheram-Borus, Hunter, \& Rosario, 1994).

The culture of violence against LGBTQ students is so entrenched in schools that teachers often ignore homophobic remarks and homophobia bullying. Less than $40 \%$ of bullying and assault incidents are reported to school personnel by LGBTQ students because they believed that reporting would exacerbate their situation; furthermore, of the students who did tell an authority figure at school, 36.7\% reported that the school staff did nothing in response (Kosciw et. al., 2012). These beliefs were verified by numerous researchers who have found both student teachers and permanent classroom teachers to feel uncomfortable and/or unprepared to confront homophobia (HaertlingThein, 2013; Malo-Juvera, 2015; Meyer, 2008; Zack, Mannheim, \& Alfano, 2010). Some scholars contend that schools are homophobic institutions (Blackburn, 2004; Owens, 1998), while others even argue that educators condone homophobia and homophobic bullying (Rivers, 1995). These positions are supported by data showing that over half of LGBTQ students reported that they have heard teachers and/or staff using homophobic language (Kosciw et. al., 2012). Clearly, if homophobic bullying and violence against not just LGBTQ students but all students is to end, the onus lies on educators to abandon the participation in a culture of violence against LGBTQ students, to go beyond reacting to homophobic language and bullying, and to become proactive agents of change.

\section{HOMOPHOBIA REDUCTION EFFORTS}

Although there are numerous published articles that use qualitative and/or descriptive methods to examine the impacts that LGBTQ themed instruction may have on students (e.g., Clark \& Blackburn, 2009; Sieben \& Wallowitz, 2009), the majority of published research that has quantitatively measured the ability of educational based strategies to reduce homophobia has been conducted with college students in human sexuality courses (e.g., Finken, 2002; Wright, Adams, \& 
Bernat, 1999). Various methods have been used to deliver interventions including panel presentations (Green, Dixon, \& Gold-Neil, 1993; Geasler, Croteau, Heineman, \& Edlund, 1995; Lance, 1987; Pagtolun-An \& Clair, 1986; Wells, 1991), campus wide educational programs (Geller, 1981), workshops (Anderson, 1981), written descriptions of homosexuals (Corley \& Pollack, 1996), specialized college courses (Waterman, Garfield \& Hoy, 2001), and even actors portraying homosexuals (Grack \& Richman, 1996). Although these efforts have shown promise, because students are victimized by homophobic bullying more frequently in middle and high school than in college, efforts to reduce homophobia should begin at much earlier ages.

\section{SECONDARY SCHOOLS}

Despite the dearth of research chronicling efforts to reduce homophobia in secondary schools, there is ample published research examining efforts to reduce bullying. A recent meta-analysis (Ttofi \& Farrington, 2011) found a total of 622 reports on bullying prevention from 1983 to 2009 and while the sheer amount of research examining bullying is encouraging, studies have found that only 6 $12 \%$ of schools' bullying policies are enumerated to include homophobic bullying (Douglas, Warwick, Kemp, Whitty, \& Aggleton, 1999; Smith, Kupferberg, Mora-Merchan, Samara, Bosley \& Osborn, 2012). With the lack of commitment from schools to confront homophobia, it is no surprise that researchers have found both preservice and inservice teachers to be reticent to engage in instruction using LGBTQ themed texts (Haertling-Thein, 2013; Malo-Juvera, 2015).

Beyond school level impediments, research on efforts to reduce homophobia and/or investigate the instruction of LGBTQ themed texts may be obstructed by the recent proliferation of "No Promo Homo" laws. "No Promo Homo" laws are laws or policies that prohibit the acceptance or promotion of homosexuality, homosexuals, or homosexual lifestyles, and are major road blocks toward combating deeply ingrained homophobic school cultures (Eskridge, 2000). These laws and/or policies can be enacted at the state level or by local school boards, and there are eight states (Alabama, Arizona, Louisiana, Mississippi, Oklahoma, South Carolina, Texas, and Utah) with laws that forbid teachers from discussing LGBTQ issues in a positive manner or sometimes even at all (GLSEN, 2012). In the face of such adversity, it is understandable that few studies examining efforts to reduce homophobia in secondary schools have been published.

A study conducted in the United States used written response questionnaires as pretest and posttest assessments to qualitatively analyze the reactions of high school students to the Gay Men's 
Chorus of Los Angeles's A-LIVE Music Project (Knotts \& Gregorio, 2011). This one session presentation consisted of musical performances of gay composers' works, short biographical lectures, and a panel discussion with gay performers. Although no statistical analyses were conducted on the data, pretest surveys were characterized as showing a general apathy to LGBTQ issues, while posttest surveys showed that 38 students developed empathy with LGBTQ issues.

A more rigorous quantitative study conducted in Australia examined the effects of a six session intervention that utilized didactic instruction, a gay and lesbian speaker panel, discussion, and reflection on homophobia in high school students (Van de Ven, 1995). Pretests, posttests and 3-month posttests consisted of the Modified Attitudes Toward Homosexuality Scale (Price, 1982), the Affective Reactions to Homosexuality Scale (Van de Ven, Bomholt, \& Bailey; 1996), the Homophobic Behavior of Students Scale (Van de Ven, Bomholt, \& Bailey; 1996), and a reader response type assignment based on work by Bleich (1989) where students wrote short stories that described a conversation between themselves and another person about homosexuality. Immediate posttest results showed that anger, behavioral intentions, and hostility toward homosexuals were significantly less homophobic while delayed posttests showed equivocal results.

\section{CURRICULA}

Although outside interventions have shown promise, due to the nature of English language arts classes and due to the availability of high quality young adult LGBTQ themed literature, there may be no better place for the inclusion of LGBTQ curricula than English/language arts classes (Banks, 2009; Clark \& Blackburn, 2009). Increasing the availability of LGBTQ texts in school libraries has been offered as a way for students to have access to these texts (Hughes-Hassell, Overberg, \& Harris, 2013); however, others have argued that all students, regardless of their sexual orientation, should read about LGBTQ students as part of whole class instruction (Cart, 1997; Hayn \& Hazlett, 2008). Blackburn \& Buckley (2005) averred that these whole class readings may be able to reduce homophobia because they afford students an opportunity to engage through readings and discussions with different mores and values that reveal "the range of gender and sexual identities that constitute everyone's world" (p. 203).

The increasing availability of resources for incorporating LGBTQ curricula is encouraging and numerous articles have chronicled the experiences of teachers and students who have utilized LGBTQ themed literature in high schools (Athanases, 1996; Hoffman, 1993; Malo-Juvera \& Spears- 
Bunton, 2015; Sieben \& Wallowitz, 2009), middle schools (Hamilton, 1998), elementary schools (Schall \& Kaufmann, 2003), and youth centers (Blackburn \& Clark, 2011). Other articles have detailed instructional methods and/or resources for incorporating LGBTQ materials in English/language arts classes (Blackburn \& Buckley, 2005; Lopez-Ropero, 2012). Although the proliferation of resources for including LGBTQ themed texts in English language arts curricula is encouraging, whether or not the use of these materials can measurably reduce students' homophobia is equivocal.

\section{CAN LITERATURE CHANGE STUDENTS' ATTITUDES?}

Many scholars have argued that reading literature and/or participating in literary instruction can change readers' attitudes (Kaywell, 1993; 2004; Nussbaum, 1990; Rosenblatt, 1995). These beliefs may be traced back to Aristotle, who argued that the goal of tragedy was to provide audiences with an experience that evokes and purges pity and fear. He termed this experience katharsis, and the degree to which a drama can achieve this is often considered a measure of the quality of a tragedy (Daniels \& Scully, 1992). Echoing Aristotle's belief in the power of drama, Hogan (2010) argued that fictive texts can impact empathic responses because literature provides readers with representations of emotions that have a clarity that is often missing in real life experiences. The ability of literature to impact emotions has been examined in several studies that found reading engaging fiction to be correlated with increased empathy in readers (Mar, Oatley, Hirsh, de la Paz \& Peterson, 2006; Mar, Oatley \& Peterson, 2009; Stansfield \& Bunce, 2014).

This ability of reading literature to impact readers beyond emotional responses was proposed by Rosenblatt (1995), who believed that literature could not only "lead to increased selfunderstanding” (p. 196), but could inspire readers to reexamine previously held beliefs. Although Rosenblatt (1995) warned that teachers should eschew literal applications of "the psychiatric possibilities of literature" (p. 198), she contended that teachers should be cognizant of the "conflicts and anxieties" that are most prevalent in adolescents and that textual choices should "have some relevance to these tensions" (p. 199). The combination of relevant textual choices and the "frank treatment of themes" was believed to enable students to not only reject socially unacceptable stances but to even embrace "new and more socially accepted attitudes" (p. 199). Thus, Rosenblatt contended that reading literature could not only have emotional impacts on readers, but could also inspire them to modify cognition and even behavior. 
The reader's role was further analyzed by Beach (1993), who categorized reader responses into five theoretical perspectives: (1) textual, which focuses on the reader's knowledge of conventions; (2) experiential, which focuses on the reader's personal experience with the text including identification with elements of the work and relating to the text; (3) psychological, which focuses on cognitive and subconscious processes according to individual differences in personality and developmental level; (4) social, which focuses on the reader's social role in responses such as classroom discussions; and (5) cultural, which focuses on how a reader's cultural roles, attitudes, values, and historical context shape responses to literature. Critical to the teaching of literature is Beach's inclusion of the social domain, which raises the importance that classroom discussions may play in responses. Thus, both Beach (1993) and Rosenblatt (1978, 1995) addressed not only textual choices and the transaction of the reading event, but also point to the critical role that classroom instruction may play in the experience of reading literature.

Literary pedagogy was impacted by Bakhtin (1981) who critiqued monologic discourse, which he described as an interaction between a teacher and student where "the student's individuality only expresses itself as an error" (Matusov, 2004, p. 7). In contrast, he espoused a dialogic pedagogy, which is "based on colliding and testing diverse ideas presented by different voices" (Matusov, 2004, p. 7). Bahktin's concepts were refined by Nystrand and Gamoran (1991) who argued that high quality literary instruction resembled a conversation between students and teachers and that the quality of discourse is contingent upon the experiences, ideas, and questions that both teachers and students bring to the classroom. In these discussions, the teacher provides thematic coherence by “interweaving discussion topics across teacher-student turns” (Nystrand \& Gamoran, 1991, p. 265). During dialogic instruction, students are allowed to use home dialects and the sharing of controversial viewpoints is not forbidden (Caughlan, Juzwik, Brosheim-Black, Kelly, \& Fine, 2013; Juzwik, Borsheim-Black, Caughlan, \& Heintz, 2013). Nystrand and Gamoran's (1991) claims that instruction based in dialogism is superior to traditional teacher centered recitation discourse have been supported by researchers who have shown that dialogism is related to increased academic performance (Applebee, Langer, Nystrand \& Gamoran, 2003). Dialogic instruction and similar techniques such as the Socratic Method have been used in many classrooms to discuss and debate numerous topics; however, research that specifically examines efforts to change students' attitudes toward various social constructs using the reading and discussion of texts has been published infrequently. 
In an experimental study, Malo-Juvera (2014) used a 5-week instructional unit based on the young adult novel Speak (Anderson, 1999) featuring written reader response exercises and group discussion to significantly reduce rape myth acceptance in urban middle school students. In a study designed to influence non-disabled students' attitudes toward disabled students, researchers (Cameron \& Rutland, 2006) used reading and discussion of texts featuring disabled and non-disabled children. Results showed that non-disabled students significantly improved their attitudes toward disabled students post intervention. In a similar study conducted in Finland, Liebkind and McAlister (1999) found that an intervention featuring stories, discussion, and peer modeling was able to decrease students' intolerance of immigrants. Much earlier studies used literature to influence elementary aged students' attitudes toward Mexican Americans (Koeller, 1970) and American Indians (Fisher, 1968).

Although great strides have been made in recent years in research concerning bullying and even in the proliferation of LGBTQ themed resources for English language arts instruction, there remains a paucity of studies that specifically examines interventions intended to measurably reduce homophobia in schools. This research is warranted because the underlying assumptions of many recent qualitative and descriptive studies that detail the use of LGBTQ themed curricula in English language arts classes is that utilizing these texts will reduce homophobia.

\section{PURPOSE}

The purpose of this study was to measure the effect of a dialogically organized instructional unit of the young adult novel Geography Club (Hartinger, 2003) on homophobia in adolescents. This study tested the following research hypothesis:

Do students who participate in the Geography Club unit have lower posttest homophobia than students who do not?

\section{METHODS}

This study used a quasi-experimental pretest-posttest design with a wait list control group. A convenience sample of seven eighth grade language arts classrooms taught by two teachers was used to create treatment and control groups. Due to having only one classroom set of texts, one teacher taught treatment and control groups with classes randomly assigned to each condition, while the other teacher taught only control groups. Participants completed pretests to measure homophobia, 
engaged in the treatment or control instruction, and were given posttests immediately after the unit had ended. Posttests were followed by a presentation by the school's TRUST counselor on homophobic bullying and by a presentation by a two person panel who discussed their experiences as gay teens who had been bullied. Posttests were administered before these two activities in order to partition the effect of literary instruction on homophobia from the didactic presentation and the panel presentation.

\section{PARTICIPANTS}

Participants were eighth grade students $(N=138)$ enrolled in English language arts classes at a Title I middle school (free-reduced lunch approximately 90\%) in a large urban school district. The sample was made up of 62 boys (45\%) and 76 girls (55\%) ranging in age from 13-16 (mean age $=14.1$ ); participants were 50\% Hispanic $(n=69)$, 36.2\% Black $(n=50)$, and 13.8\% White $(n=19)$. All students returned parent consent forms and completed student assent forms. Prior to and during the study, students were given the option to stop reading the novel at any time. None availed themselves of this opportunity.

\section{THE SCHOOL SITE}

When discussing using LGBTQ themed literature with students it is critical to know the school setting so that curricular options and choices can be understood in context. The school where the study took place was a large middle school that served about 2000 students in a major urban school district. The school had an extremely high free/reduced lunch rate (above 90\%) as well as a high suspension rate for numerous issues such as fighting, bullying, theft, and even assault on both students and teachers. Both teachers who participated in this study reported that the general atmosphere of the school was not a welcoming place for students who displayed anything other than heterosexual behavior and conveyed that they would both address homophobic language use with their students during the first week of school. Although their classrooms could be considered safe spaces for all students regardless of race, religion, or sexual orientation, the school itself could not be described as such. Beyond student behaviors that would readily be categorized as homophobic bullying, it was reported that some members of the faculty and staff exhibited homophobia by proselytizing religious intolerance for homosexuality to students whom they believed may not be straight. Despite the fact that the school administration and the school counselors were strongly in 
favor of LGBTQ issues being addressed, there were very few places in the school where LGBTQ issues were being discussed and the school did not have a gay straight student alliance group.

\section{GEOGRAPHY CLUB}

Geography Club, by Brent Hartinger, is a young adult novel about a gay teen who discovers he is not the only LGBTQ student at his conservative high school and starts an LGBTQ support group disguised as a geography club. Notably, the book contains more than one character who is LGBTQ as there are characters who are gay (Russel, Kevin, and Ike), lesbian (Teresa), bisexual (Min), and even students who have questioned their sexual orientation (Brian). The novel has been recognized for its positive portrayals of LGBTQ characters (Norton \& Vare, 2004), and Zanitsch (2009) lauded the text as one that provides a nuanced examination of "young people struggling with the social and personal implications of sexual orientation and gender identity" (p. 85).

Geography Club has been identified as a recommended LGBTQ text for classroom instruction (Gallo, 2004), as a middle school level text (Curwood, Schliesman, \& Horning, 2009), and even as a text to utilize in Advanced Placement literature classes (Miller \& Slifkin, 2010). Author Brent Hartinger has been named as a notable author of young adult fiction (Letcher, 2009) and commended as "gifted young" writer (Cart, 2004); furthermore, the popularity of the text has been reinforced by its adaptation into a feature film (Entin, 2013). The text has garnished numerous awards and accolades such as being a finalist for the prestigious Lambda Literary Award in 2003, a Children’s Book Award Notable Book, an American Library Association "Popular Paperback,” a USA Today “Great High School Book,” a Young Adult Library Services Association "Must Read” book, as well as being nominated for and winning local awards in California, Connecticut, Maryland, New York, Tennessee, Texas, Rhode Island, and Washington (Hartinger, 2016). Perhaps as a result of the aforementioned recommendations and accolades, Geography Club has been described as having membership in the "canon of queer YA literature" (Banks, 2009, p. 35).

\section{GeOgRAPHy Club UNIT}

The Geography Club unit lasted five weeks and all reading was conducted in class using sustained silent reading. Student and teacher out loud readings were completed when reviewing and highlighting specific sections of the texts. The majority of instruction centered on reader response 
writing assignments and discussions. Writing was completed in journals and followed by small group and then whole class discussion. There were seven reader response papers/discussions:

1. What kind of bullying have you seen in school? How do you think bullying could be reduced or stopped in your school? (completed prior to commencing reading)

2. Why do you think gay teens attempt suicide at 3-4 times the rate of heterosexual teens? (completed after a scene where Ike discloses he attempted suicide)

3. Write a conversation where you attempt to convince Russell to let Brian Bund in the Geography Club. (completed after a scene where Min argues to allow Brian in the club)

4. If Kevin Land could choose his sexual orientation, what would he pick? Why? (completed after a scene where Kevin taunts Russell with homophobic epithets in front of their peers)

5. What are three important themes of Geography Club? (completed after finishing the novel)

6. Who are your favorite two characters from the book and why? (completed after finishing the novel)

7. Do you think this school needs a gay straight alliance club? (completed after finishing the novel)

\section{MEASURES}

Because most scales that measure homophobia were designed for use with college aged participants, this study used a researcher created scale, the Adolescent Homophobia Index (AHI; see Table 7 for AHI items), to measure participants' homophobia. The AHI consists of 11 Likert style items with choices ranging from strongly agree to strongly disagree designed to measure adolescents' homophobia in educational and social situations. Questions for the AHI were developed by the researcher as well as using questions modified from and inspired by items from the Homophobic Behavior of Students Scale (Van de Ven, Bornholt, \& Bailey, 1996), the Homosexism Scale: Short Form (Hansen, 1982), Attitudes Toward Lesbians and Gay Men Scale (Herek, 1984), the Homophobia Attitude Scale (Aguero, Bloch, \& Byrne, 1984), Attitudes Toward Homosexuality Scale (Black \& Stevenson, 1984), Modern Homophobia Scale - Gay Men/Lesbians (Raja \& Stokes, 1998), and the Homophobia Scale (Wright, Adams, \& Bernat, 1999). 


\section{RESULTS}

\section{ADOLESCENT HOMOPHOBIA INDEX}

Analysis revealed the AHI to have a Cronbach's alpha of $\alpha=.86$. This score is considered to be a better than an acceptable level of reliability (Kline, 1999) and is comparable to other scales used to measure homophobia such as the Homophobic Behavior of Students Scale (.81 - .86; Van de Ven, Bornholt, \& Bailey, 1996) and the Modern Homophobia Scale (.85 - .91; Raja \& Stokes, 1998).

\section{PRELIMINARY ANALYSES}

One way ANOVAs were conducted to determine if there were any differences between students on pretest homophobia based on sex or race. Results showed that girls had significantly lower levels of pretest homophobia than boys and that pretest homophobia was significantly higher in Black students than in Hispanic Students (see Table 1). There were no differences between other possible comparisons of race.

\section{TABLE 1}

Pretest Homophobia by Sex and Race

\begin{tabular}{|c|c|c|c|c|c|c|c|c|}
\hline \multirow{3}{*}{ SEX } & \multicolumn{2}{|c|}{ HISPANIC $(N=69)$} & \multicolumn{2}{|c|}{ BLACK $(N=50)$} & \multicolumn{2}{|c|}{ White $(N=19)$} & \multicolumn{2}{|c|}{$\operatorname{ALL}(N=138)$} \\
\hline & MEAN & STANDARD & MEAN & STANDARD & MEAN & STANDARD & MEAN & STANDARD \\
\hline & & DEVIATION & & DEVIATION & & DEVIATION & & DEVIATION \\
\hline ALL & $20.36^{\mathrm{A}}$ & 6.60 & $25.04^{\mathrm{A}}$ & 8.64 & 23.32 & 6.31 & 22.46 & 7.63 \\
\hline BOYS & 23.54 & 7.81 & 31.25 & 7.78 & 26.38 & 5.45 & $26.50^{\mathrm{b}}$ & 7.98 \\
\hline GIRLS & 18.13 & 4.37 & 21.19 & 6.54 & 18.00 & 3.52 & $19.17^{b}$ & 5.49 \\
\hline
\end{tabular}

\section{MAIN EFFECTS}

To test the hypothesis that participants in the instructional unit would have lower posttest homophobia than participants in the control group, a 2 (control or treatment) x 2 (male or female) x 3 (Hispanic, Black, or White) analysis of covariance (ANCOVA) was conducted using AHI pretest scores as a covariate, posttest scores as a dependent variable, and Group, Sex, and Race as factors. Results showed that students in the treatment group had significantly lower posttest homophobia 
than students in the control group, $F(1,107)=19.97, p<.001, \eta^{2}=.16$, indicating that the unit was effective at reducing participants' homophobia (see Table 2).

TABLE 2

Posttest Homophobia by Group

\begin{tabular}{|c|c|c|c|c|c|c|}
\hline \multirow{3}{*}{ GROUP } & \multicolumn{2}{|c|}{ PRETEST } & \multicolumn{2}{|c|}{ POSTTEST } & \multicolumn{2}{|c|}{ AdJUSTED POSTTEST } \\
\hline & MEAN & STANDARD & MEAN & STANDARD & MEAN & STANDARD \\
\hline & & DEVIATION & & DEVIATION & & ERROR \\
\hline Control & 23.60 & 8.08 & 24.67 & 8.62 & $23.13^{a b}$ & .54 \\
\hline Treatment & 20.87 & 6.71 & 17.90 & 6.24 & $19.500^{a b}$ & .61 \\
\hline
\end{tabular}

a. Covariates appearing in the model are evaluated at the following values: AHI Pretest $=22.22$. b. Difference is significant at $p<.001$.

Race was also a significant predictor of posttest scores with Black students having significantly higher posttest homophobia than Hispanic or White students, $F(3,107)=6.14, p<.001, \eta^{2}=.14$ (see Table 3). There was no significant difference in posttest homophobia between Hispanic and White students $(p>.05)$. Sex was also a significant predictor of posttest homophobia with girls having significantly lower posttest homophobia than boys $\mathrm{F}(1,107)=5.00, p<.05$, ${ }^{2} 2=.05$ (see Table 4). Finally, the interaction between Sex and Race was also significant $F(2,107)=4.19, p<$ $.05, \eta^{2}=.02$ (see Table 5). By examining Table 5, it can be seen that Black males demonstrated higher homophobia post-treatment than all other combinations of Race and Sex. In fact, Black males actually increased their levels of homophobia posttest, though not significantly $(p>.05)$. 
TABLE 3

Posttest Homophobia by Race

\begin{tabular}{|c|c|c|c|c|c|c|}
\hline \multirow{3}{*}{ RACE } & \multicolumn{2}{|c|}{ PRETEST } & \multicolumn{2}{|c|}{ POSTTEST } & \multicolumn{2}{|c|}{ AdJUsted POSTTEST } \\
\hline & MEAN & STANDARD & MEAN & STANDARD & MEAN & STANDARD \\
\hline & & DEVIATION & & DEVIATION & & ERROR \\
\hline Hispanic & 20.29 & 6.51 & 18.63 & 6.64 & $20.65^{\mathrm{ab}}$ & .46 \\
\hline Black & 25.02 & 8.52 & 25.52 & 9.44 & $23.61^{a b}$ & .62 \\
\hline White & 22.79 & 6.27 & 20.64 & 5.58 & $19.68^{a b}$ & .96 \\
\hline
\end{tabular}

a. Covariates appearing in the model are evaluated at the following values: AHI Pretest $=22.22$. b. Difference is significant at $p<.001$.

TABLE 4

Posttest Homophobia by Sex

\begin{tabular}{|c|c|c|c|c|c|c|}
\hline \multirow{3}{*}{ GROUP } & \multicolumn{2}{|c|}{ PRETEST } & \multicolumn{2}{|c|}{ POSTTEST } & \multicolumn{2}{|c|}{ ADJUSTED POSTTEST } \\
\hline & MEAN & STANDARD & MEAN & STANDARD & MEAN & STANDARD \\
\hline & & DEVIATION & & DEVIATION & & ERROR \\
\hline Boys & 26.46 & 8.12 & 25.38 & 9.00 & $22.38^{\mathrm{ab}}$ & .64 \\
\hline Girls & 19.24 & 5.37 & 18.35 & 6.19 & $20.24^{\mathrm{ab}}$ & .59 \\
\hline
\end{tabular}

a. Covariates appearing in the model are evaluated at the following values: AHI Pretest $=22.22$. b. Difference is significant at $p<.05$.

TABLE 5

Interaction of Race and Sex on Posttest Homophobia

\begin{tabular}{|c|c|c|c|c|c|c|c|}
\hline & & \multicolumn{2}{|c|}{ PRETEST } & \multicolumn{2}{|c|}{ POSTTEST } & \multicolumn{2}{|c|}{ ADJUSTED POSTTEST } \\
\hline \multirow[t]{2}{*}{ SEX } & RACE & MEAN & STANDARD & MEAN & STANDARD & MEAN & STANDARD \\
\hline & & & DEVIATION & & DEVIATION & & ERROR \\
\hline \multirow[t]{3}{*}{ Male } & Hispanic & 23.54 & 7.81 & 20.96 & 7.96 & $20.72^{a}$ & .72 \\
\hline & Black & 31.25 & 7.78 & 33.00 & 7.55 & $25.85^{\mathrm{a}}$ & 1.04 \\
\hline & White & 26.38 & 5.45 & 24.50 & 3.51 & $20.58^{a}$ & 1.31 \\
\hline \multirow[t]{3}{*}{ Female } & Hispanic & 18.13 & 4.37 & 17.08 & 5.14 & $20.58^{a}$ & .61 \\
\hline & Black & 21.19 & 6.54 & 20.92 & 7.35 & $21.37^{a}$ & .70 \\
\hline & White & 18.00 & 3.52 & 15.50 & 2.88 & $18.78^{a}$ & 1.45 \\
\hline
\end{tabular}

a. Covariates appearing in the model are evaluated at the following values: AHI Pretest $=22.22$. 


\section{POST-HOC FACTOR ANALYSIS}

Because homophobia has been found to have numerous constructs in previous studies (Herek, 1984; Pongratz, 2005), post-hoc factor analyses were conducted to investigate the dimensionality of the AHI and to determine whether the effect of treatment was concentrated in any specific aspects of homophobia or if it was equally distributed. In order to discover the underlying factors of the AHI, exploratory factor analysis was conducted on AHI pretests using principal components extraction with Varimax rotation. Initial analysis revealed an acceptable Kaiser-Meyer-Olkin value of .90 and a significant result of Bartlett's Test of Sphericity $(p<.001)$ indicating that the sample was suitable for factor analysis.

Consideration of the scree plot, eigenvalues, and the theoretical framework of AHI items led to the acceptance of a three component solution that accounted for $64.22 \%$ of variance. Component 1, Interpersonal Homophobia (eigenvalue $=4.27,38.81 \%$ of variance), was considered to represent attitudes toward school based and social interactions with individuals who are or who are perceived to be homosexual. Component 2, Attitudes toward Homophobia (eigenvalue = 1.53, $13.87 \%$ of variance), was considered to represent respondents' attitudes toward displays of homophobic behavior in others. Component 3, Sexuality as a Choice (eigenvalue $=1.27,11.55 \%$ of variance), was considered to represent the belief that sexual orientation is a choice (see Table 6 for factor items and loadings).

To determine whether treatment was more effective at reducing homophobia for any of the three components, further analysis was conducted on only treatment group scores. Summed pretest and posttest scores were calculated for the three components derived through factor analysis: Interpersonal Homophobia, Attitudes toward Homophobia, and Sexuality as a Choice. Repeated measures ANOVAs were then conducted on each factor's summed scores to discover whether they changed significantly from pretest to posttest and if so, to ascertain the effect size for each. Using a Bonferroni correction, each repeated measures ANOVA was tested at the .017 level. Results revealed that the effect size for Homosexuality as a Choice was almost two times larger than the effect size for Attitudes toward Homophobia, and that Interpersonal Homophobia increased slightly but not significantly posttest (see Table 7). Thus, treatment was far more effective at refuting the belief that sexual orientation is a choice, than it was at reducing tolerance of homophobia in others, 
while it was not significantly effective at reducing homophobia in terms of social situations inside and outside of school.

\section{TABLE 6}

Summary of Exploratory Factor Analysis Results for Adolescent Homophobia Index Using Principal Components Extraction and Varimax Rotation

\begin{tabular}{|c|c|c|c|}
\hline \multirow[b]{2}{*}{ ITEM (QUESTION \#) } & \multicolumn{3}{|c|}{ FACTOR LOADINGS } \\
\hline & $\begin{array}{l}\text { INTERPERSONAL } \\
\text { HOMOPHOBIA }\end{array}$ & $\begin{array}{c}\text { ATTITUDES } \\
\text { TOWARD } \\
\text { HOMOPHOBIA }\end{array}$ & $\begin{array}{l}\text { SEXUALITY AS } \\
\text { A CHOICE }\end{array}$ \\
\hline $\begin{array}{l}\text { I would feel uncomfortable being seen at the } \\
\text { mall with a group of friends if one was gay. (Q6) }\end{array}$ & $.87^{a}$ & .22 & .01 \\
\hline $\begin{array}{l}\text { I would be uncomfortable if a gay student sat } \\
\text { next to me on the school bus. (Q11) }\end{array}$ & $.81^{\mathrm{a}}$ & .06 & .29 \\
\hline $\begin{array}{l}\text { It would bother me if a teacher assigned me to } \\
\text { do group work with a gay student. (Q8) }\end{array}$ & $.81^{\mathrm{a}}$ & .15 & .10 \\
\hline $\begin{array}{l}\text { I would not join a study group if a gay student } \\
\text { was in it. (Q2) }\end{array}$ & $.78^{a}$ & .24 & .07 \\
\hline $\begin{array}{l}\text { If a friend told me he/she was gay, I would not } \\
\text { be his/her friend anymore. (Q4) }\end{array}$ & $.76^{\mathrm{a}}$ & .12 & .29 \\
\hline $\begin{array}{l}\text { Gay teens should not be allowed to go to school } \\
\text { dances as couples. (Q10) }\end{array}$ & $.72^{\mathrm{a}}$ & .19 & -.07 \\
\hline $\begin{array}{l}\text { Many gay kids who get beat up ask for it by } \\
\text { acting so gay. (Q5) }\end{array}$ & .52 & .27 & .27 \\
\hline $\begin{array}{l}\text { It bothers me when people put down gay } \\
\text { students. (Q7) }\end{array}$ & .31 & $.72^{b}$ & .06 \\
\hline $\begin{array}{l}\text { Schools should not have clubs like gay straight } \\
\text { alliance groups. (Q1) }\end{array}$ & .20 & $.67^{\mathrm{b}}$ & -.03 \\
\hline $\begin{array}{l}\text { There is nothing wrong with calling students } \\
\text { "fag" or "queer" if they are gay. (Q3) }\end{array}$ & .30 & -.11 & $.78^{\mathrm{c}}$ \\
\hline $\begin{array}{l}\text { Gay teens could be straight if they wanted to be. } \\
\text { (Q9) }\end{array}$ & -.11 & .55 & $.63^{\mathrm{c}}$ \\
\hline Eigenvalues & 4.27 & 1.53 & 1.27 \\
\hline$\%$ of variance & 38.81 & 13.87 & 11.54 \\
\hline
\end{tabular}

Note: Factor loadings over .60 appear in bold. a. Loads into Interpersonal Homophobia. b. Loads into Attitudes toward Homophobia. c. Loads into Sexuality as a Choice. 


\section{TABLE 7}

Scores and Effect Sizes of Components Derived Through Exploratory Factor Analysis

\begin{tabular}{|c|c|c|c|c|c|c|c|c|}
\hline \multirow[b]{2}{*}{ COMPONENT } & \multicolumn{3}{|c|}{ PRETEST } & \multicolumn{3}{|c|}{ POSTTEST } & \multirow[b]{2}{*}{ SIGNIFICANCE } & \multirow[b]{2}{*}{$\begin{array}{l}\text { EFFECT } \\
\text { SIZE }\end{array}$} \\
\hline & MEAN & SD & $\begin{array}{l}\text { ITEM } \\
\text { MEAN }\end{array}$ & MEAN & SD & $\begin{array}{l}\text { ITEM } \\
\text { MEAN }\end{array}$ & & \\
\hline $\begin{array}{l}\text { Interpersonal } \\
\text { Homophobia }\end{array}$ & 10.66 & 5.25 & 1.78 & 10.95 & 5.50 & 1.83 & $p=.21$ & $\mathrm{n} / \mathrm{a}$ \\
\hline $\begin{array}{l}\text { Attitudes toward } \\
\text { Homophobia }^{\mathrm{b}}\end{array}$ & 4.41 & 1.83 & 2.21 & 3.34 & 1.41 & 1.67 & $p<.001$ & .25 \\
\hline $\begin{array}{l}\text { Sexuality as a } \\
\text { Choice }^{\text {b }}\end{array}$ & 4.98 & 1.44 & 2.49 & 3.48 & 1.55 & 1.74 & $p<.001$ & .41 \\
\hline
\end{tabular}

Effect size estimated using partial $\eta^{2}$. Significance tested with Bonferroni correction at .017 .

a. Six items in component. b. Two items in component.

\section{POST-HOC BACKLASH ANALYSIS}

Researchers involved in interventions designed to influence participants' attitudes toward constructs such as rape myth acceptance (Malo-Juvera, 2014), wife and child abuse (Godenzi \& Du Puy, 2001) and acceptance of violence (Hilton, 2000) have shown a concern that interventions may cause a change in the undesired direction in some participants' attitudes that has been found in previous research (Jaffe, Suderman, Reitzel, \& Kellip, 1992). Because homophobia and homophobic bullying are forms of violence similar to the aforementioned constructs, analysis was conducted to determine if there was a backlash to treatment in this study.

Treatment group participants $(n=6)$ with pretest AHI scores at or above one standard deviation from the mean $(\mathrm{AHI} \geq 30)$ were identified as having high pretest levels of rape myth acceptance. If there were a backlash to treatment, participants in this group would show significantly higher levels of homophobia posttest, if there was no backlash to treatment, they would show no significant change or show a significant decrease in posttest AHI scores. A repeated measures ANOVA was conducted using pretest $(\bar{x}=35.33, S D=2.42)$ and posttest $(\bar{x}=26.33, S D=5.28)$ AHI scores. Results showed that scores were significantly lower posttest, Wilks's $\Lambda=.23, F(1,5)=$ $16.64, p=.01$, partial $\eta^{2}=.77$. In order to discover whether or not this sizable reduction was due to regression to the mean, an ANCOVA was conducted with both treatment and control group participants who had AHI pretest scores at or above 30 using AHI pretest scores as a covariate, posttest scores as a dependent variable, and Group as a factor. Results showed that students with high pretest homophobia in the treatment group $(n=6)$ had significantly lower posttest homophobia 
than students with high pretest homophobia in the control group $(n=11), F(1,17)=21.65, p<.001$, $\eta^{2}=.67$ (see Table 8). The findings support that treatment was not only effective in avoiding a backlash to treatment, but that it was effective in significantly reducing homophobia in participants with high pretest homophobia.

TABLE 8

AHI Scores of Participants with High Pretest Homophobia by Group

\begin{tabular}{|c|c|c|c|c|c|c|}
\hline \multirow{3}{*}{ GROUP } & \multicolumn{2}{|c|}{ PRETEST } & \multicolumn{2}{|c|}{ POSTTEST } & \multicolumn{2}{|c|}{ ADJUSTED POSTTEST } \\
\hline & MEAN & STANDARD & MEAN & STANDARD & MEAN & STANDARD \\
\hline & & DEVIATION & & DEVIATION & & ERROR \\
\hline Control & 35.57 & 5.47 & 35.71 & 7.23 & $35.63^{a b}$ & 1.07 \\
\hline Treatment & 35.33 & 2.42 & 26.33 & 5.28 & $26.52^{a b}$ & 1.64 \\
\hline
\end{tabular}

a. Covariates appearing in the model are evaluated at the following values: AHI Pretest $=35.50$. b. Difference is significant at $p<.001$.

\section{DISCUSSION}

The purpose of this study was to determine whether an instructional unit based on the young adult novel Geography Club could reduce homophobia in adolescents. The finding that the unit was able to significantly lower homophobia in participants is especially noteworthy as it is the first published empirical study to show that literary instruction of a young adult LGBTQ themed text can measurably reduce adolescents' homophobia. Furthermore, by using a quasi-experimental pretest posttest design, this study provides evidence to support a body of research (e.g., Athanases, 1996; Mitchell, 2009; Sieben \& Wallowitz, 2009) that has espoused the use of LGBTQ themed literature in English language arts instruction. Considering that higher levels of homophobia are correlated with increased acceptance of bullying which has been linked to elevated proclivity to engage in bullying (Carrera-Fernández, Lameiras-Fernández, Rodríguez-Castro, \& Vallejo-Medina, 2013), this is an especially important finding and strongly argues that reducing homophobia should be a priority for every school.

Whether an intervention can impact those who need it the most is always a consideration, and the results of backlash analysis provide important insights about how students with highly homophobic attitudes were affected by instruction. Not only did analysis reveal that there was no backlash to treatment but it further found that students with high pretest homophobia experienced 
significant and sizable reductions in homophobia. This may provide a counter narrative to those who believe that some students may be too disruptive or may not take instruction seriously when dealing with LGBTQ issues; furthermore, the results support Rosenblatt's (1995) assertions that transactions with literature could afford readers an opportunity to reexamine previously held beliefs, even if those beliefs are held to a strong degree. Finally, to be able to find such a large effect size with such a small sample for analysis speaks volumes to the efficacy of this unit.

The results of post hoc analysis on the components derived through factor analysis show which constructs of homophobia were most impacted by the intervention. The component that was most impacted by intervention was Sexuality as a Choice, which consisted of two items, one of which asked if respondents thought that "gay kids could be straight if they wanted to." The reduction of this construct could be directly related to the content of Geography Club and to discussions surrounding a character, Kevin, who is what many literary scholars may identify as the stereotypical closeted jock motif. Kevin is a star athlete who is gay but maintains the façade of heterosexuality while engaging in a romantic relationship with the novel's protagonist, Russell. One of the reader response questions asked students whether or not Kevin would choose to be heterosexual if he could, and according to reports from the teachers, intense discussions followed, with most students agreeing that if he could choose his sexuality, it would be heterosexual in order to maintain his social status as a well-known student-athlete.

This shift in attitudes represents an embracing of biological determinism, which is the belief that sexual orientation is predominantly determined by immutable biological factors (Hegarty, 2002). This is critical because adherence to this viewpoint has been correlated with lower levels of homophobia while subscribing to the belief that sexual orientation is a choice has been correlated with higher levels of homophobia (Hegarty \& Pratto, 2001). This may be because "stigmata understood to be under personal control elicit more hostility, less pity and fewer intentions to help than stigmata understood to be beyond personal control” (Hegarty, p. 155, 2002). The analysis and discussion of the stereotypical "closeted jock" may have offered students the opportunity to reevaluate their beliefs about factors that influence sexual orientation and the results of this study argue that discussions of biological determinism may be an essential part of any effort to reduce homophobia.

Attitudes toward Homophobia, the factor containing items relating to tolerance for witnessing homophobic behaviors, was also significantly reduced, indicating that participants were 
less likely to accept others' homophobic speech and actions. The significant and sizable reduction in this construct could be because the novel addressed not only homophobic bullying, but also rumor spreading, peer pressure, and physical assault. The change in attitudes measured by this factor could represent a shift in attitudes similar to that which is often sought by interventions aimed at changing the behavior of bystanders who witness events such as bullying and date rape. The behavior of bystanders is often targeted as an opportunity to prevent and/or stop bullying because researchers have found that $85 \%$ of bullying incidents included bystanders who either provided attention or participated in the incident (Craig \& Pepler, 1995, 1997). Furthermore, the presence of an audience has been found to encourage and protract bullying (Craig \& Pepler, 1995, 1997; Salmivalli, Lagerspetz, Bjorkqvist, \& Kaukiainen, 1996). While it is beyond the scope of this study to measure, it is hoped that this decrease in acceptance of homophobic displays would also reduce the likelihood that these participants would watch or encourage homophobic bullying.

On the other hand, the factor that accounted for the largest amount of variance, Interpersonal Homophobia, was not significantly reduced. This component related to respondents' comfort level interacting with LGBTQ peers in a variety of social and educational situations such as socializing at the mall, going to school dances, and joining study groups. While these results are disappointing, it may be that a five week unit is not long enough to combat years of exposure to homophobic messages at home, in the media, and in schools. Considering the sizable reductions in the other two factors, the results here argue strongly for a more consistent inclusion of LGBTQ themed materials and topics in curricula across subjects and grade levels.

Although the effect of instruction showed significant reductions in homophobia, results also showed that Race and Sex were significant predictors of posttest homophobia, and that there was a significant interaction effect between Race and Sex on posttest homophobia. Specifically, Black participants had significantly higher homophobia than Hispanic and White participants at the start and finish of the study. These results echo other studies that have found Blacks to have higher homophobia than Whites (Durrel, Choing, \& Battle, 2007; Hudson \& Ricketts, 1980; Waldner, Sikka, \& Baig, 1999). It is important to note that whether or not homophobia is generally higher in Black populations is equivocal as Levitt and Klassen (1976) found Blacks to have lower homophobia, while other studies reported mixed results when examining race and homophobia (Bonilla \& Porter, 1990; Herek \& Capitanio, 1995; Lewis, 2003). This is an area in need of more research, especially studies that specifically investigate adolescents' homophobia; however, because 
there are other variables that influence homophobia such as religious conservatism, researchers should be wary of accepting any racial category as a unidimensional group.

The effect of Sex on homophobia was significant but less powerful than Race showing that girls had lower homophobia at the start and the finish of the study. While some may interpret that the unit was more effective for girls, the converse may be actually more accurate, that the unit was more effective at reducing homophobia in boys. Females in the study may have been hindered by a floor effect, in that their scores could not move much lower, while boys clearly had much more room to move in the desired direction; however, because boys started so much higher, they were unable to reach the level of their female classmates. These findings echo other studies that have found girls to be less tolerant of rape myths pretest and thus more susceptible to a floor effect (Hilton, Harris, Rice, Krans \& Lavigne, 1998; Malo-Juvera, 2014; Smith \& Welchans, 2000). The interaction effect of Race and Sex showed that Black males had significantly higher posttest homophobia than all other possible combinations of Race and Sex and researchers may want to conduct further investigations in order to determine whether the results are isolated to this study and/or whether there are more effective ways to reduce homophobia specifically for adolescent Black males.

\section{IMPLICATIONS FOR RESEARCH}

The finding that dialogically based literary instruction reduced homophobia in this study has implications for future research as this study could be replicated using different novels and/or by examining how literary instruction can impact homophobia at different school types, such as high school or elementary, and with different demographic groups. The study of dialogic instruction of young adult novels could also be extended to different social constructs such as attitudes toward suicide, the disabled, poverty, violence, or racism. Furthermore, researchers may want to consider expanding studies that examine literary instruction by using mixed methods designs incorporating the collection and analysis of qualitative data such as student work, interviews with students, focus group interviews, and observations of discussions that would provide an opportunity to develop an understanding of how students experience this type of instruction.

This study also offers researchers a model for pinpointing effect size through the use of exploratory factor analysis combined with Bonferroni corrected repeated measures ANOVAs. By using this model of post hoc analysis, researchers analyzing survey type data can get a more precise view of whether changes are global across a scale or if they are concentrated in specific constructs. 
Finally, the creation and factor analysis of a scale to measure school based homophobia in adolescents provides researchers with a tool to use in future studies.

\section{IMPLICATIONS FOR TEACHING}

The findings of this study have far ranging implications for teachers, teacher training programs, and school districts. Perhaps most importantly, the results argue that because there are measurable benefits to including LGBTQ themed texts in curricula, namely the opportunity to reduce adolescents' homophobia, that it would be irresponsible for any schools serious about reducing bullying to censor LGBTQ themed texts from curricula. There are numerous quality LGBTQ themed texts that teachers could utilize as part of instruction at all levels, and teacher education programs should make including these in coursework for all preservice teachers a priority. Considering that researchers (Haertling-Thein, 2013; Malo-Juvera, 2015) have found that many preservice and inservice teachers are reluctant to use LGBTQ themed literature, this study could be used as part of teacher education and professional development as a strong justification to the reticent/unwilling about the benefits of using LGBTQ texts. Furthermore, because Malo-Juvera (2015) found that preservice English teachers felt unprepared to lead discussions about LGBTQ topics, the success of this study argues there is a need to introduce preservice and inservice teachers to dialogic instruction, especially when dealing with issues that some may find controversial.

\section{LIMITATIONS}

While this study provides a rigorous empirical examination of the effect of literary instruction on homophobia, it is not without its limitations. Perhaps the most important limitation is that while two teachers participated in this study, only one teacher taught Geography Club because there was only one class set of texts available. Although this may present questions of whether the success of the unit could be ascribed to a coaching effect, the variance between effect of treatment based on sex and race as well as the finding of three factors with varying significance levels and effect sizes through exploratory factor analysis argue strongly against the presence of a coaching effect.

This study only focuses on only one text; however, it is important to note that both teachers' discussed and interrogated other texts such as The Absolutely True Diary of a Part Time Indian (Alexie, 2007), Monster (Myers, 1999), Of Mice and Men (Steinbeck, 1937), and Speak (Anderson, 1999) for issues such as classism, sexism, institutionalized racism, rape myths, and xenophobia 
throughout the school year. Thus, not only were the teachers knowledgeable at managing classroom discussions and handling controversial topics, but their students were also experienced at participating in dialogically based literary instruction, and this should be considered when generalizing results. It is not the intent of this research to imply that teachers without this type of experience would be able or willing to conduct a unit of instruction such as that which is described here.

Furthermore, the instructional unit described was aimed at all students, regardless of sexual orientation or gender identity, with the intent of reducing violence toward LGBTQ students; therefore, it was most important to the success of this unit that it impacted students who may have been likely to participate in homophobic bullying, to engage in the use of homophobic epithets, or to be passive or even encouraging bystanders to either of the aforementioned behaviors. There are a myriad of LGBTQ themed young adult texts that offer multiple possibilities for instruction and it is not the intent of this study to limit the purposes for instructing LGBTQ themed texts to combating homophobia and bullying.

Sample size is often a limitation in applied educational research and although 138 participants would appear as an amount large enough for powerful analysis, when considering students as nested in classrooms when using hierarchal linear modeling, the important variable in terms of quantity becomes the level-2 sample size. In this study, the level-2 sample would consist of seven classrooms, which falls well below the recommended minimum for level-2 variables and thus makes it highly unlikely that adequate power would be realized to detect anything but the largest effect sizes (Bell, Morgan, Schoeneberger, Loudermilk, Kromrey, \& Ferron, 2010; Maas \& Hox, 2004, 2005). Therefore, in order to maintain adequate power to avoid a Type II error, it was decided to conduct main analysis at the student level using ANCOVA.

When conducting research in schools, it is always important to be as unobtrusive as possible, especially in terms of observing and recording conversations. In this study, it is highly likely that the presence of outside researchers in the classroom would have altered how students engaged in discussions; therefore, it was decided that the only data collected would be the short pre and posttest surveys. Similarly, in order to decrease the possibility of influencing student responses and/or reducing parental consent and student assent, student work was not collected. Thus, it is not the intent nor ability of this study to provide an understanding of how students experienced instruction. Furthermore, it is not possible to determine to what degree each of the components of the unit - 
reading the text, reader response assignments, or the dialogic discussions - impacted homophobia. Finally, this study did not utilize delayed posttests so it is not possible to know if the changes in homophobia were temporary or enduring.

It is also important to note that this study was able to be conducted because of the strong contractual provisions concerning academic freedom that teachers had in their school district. Many school districts have diluted or completely eliminated academic freedom in the pursuit of higher standardized test scores, and it is critical that educators at all levels realize a major role of teachers unions is to ensure teacher choice of instructional materials, and that as their power diminishes, so does the autonomy of teachers everywhere.

\section{CONCLUSION}

Despite the huge strides in gaining rights for LGBTQ peoples on a national level such as the 2015 Supreme Court ruling that legalized gay marriage, changing the culture of violence that many LGBTQ adolescents suffer on a daily basis cannot wait for a "trickle down" effect on equality. By showing that a literary instructional unit of an LGBTQ themed text could produce significant reductions in adolescents' homophobia, it is hoped that school systems and teacher preparation programs identify the inclusion of texts that represent a wide array of sexual orientations and gender identities as a priority. In order to strive toward equality for all students, it will be necessary for teachers, administrators, researchers, and professors to re-examine their complicity with the institutionalized heteronormativity that is cloaked behind a standards and high stakes testing fetish that makes teaching "controversial" texts or going "off-script" a potentially career ending choice for classroom teachers.

\section{REFERENCES}

Aguero, J. E., Bloch, L., \& Byrne, D. (1984). The relationships among sexual beliefs, attitudes, experience, and homophobia. Journal of Homosexuality, 10(1-2), 95-107.

Alexie, S. (2007). The absolutely true diary of a part-time Indian. New York: Little, Brown.

Anderson, C. L. (1981). The effect of a workshop on attitudes of female nursing students toward male homosexuality. Journal of Homosexuality, 7(1), 57-69.

Anderson, L. H. (1999). Speak. New York, NY: Farrar Straus Giroux. 
Athanases, S.Z. (1996). A gay-themed lesson in an ethnic literature curriculum: Tenth graders' responses to “Dear Anita.” Harvard Educational Review, 66, 231-256.

Applebee, A. N., Langer, J. A., Nystrand, M., \& Gamoran, A. (2003). Discussion-based approaches to developing understanding: Classroom instruction and student performance in middle and high school English. American Educational Research Journal, 4O(3), 685730.

Bakhtin, M. M. (1981). The dialogic imagination. (M. Holquist, Ed.; C. Emerson \& M. Holquist, Trans.). Austin: University of Texas Press.

Banks, W.P. (2009). Literacy, sexuality, and the value(s) of queer young adult literatures. English Journal, 98(4), 33-36.

Beach, R. (1993). Reader response theories. Urbana, IL: National Council of Teachers of English.

Bell, B.A., Morgan, G.B., Schoeneberger, J.A., Loudermilk, B.L., Kromrey J.D., \& Ferron, J.M. (2010). Dancing the sample size limbo with mixed models: How low can you go? SAS Global Forum 2010. Paper. 197-2010.

Bernat, J.A., Calhoun, K.S., Adams, H.E., Zeichner, A. (2001). Homophobia and physical aggression toward homosexual and heterosexual individuals. Journal of Abnormal Psychology, 110(1), 179-187.

Black, K. N., \& Stevenson, M. R. (1984). The relationship of self-reported sex-role characteristics and attitudes toward homosexuality. Journal of Homosexuality, 10(1-2), 83-93.

Blackburn, M. V. (2004). Understanding agency beyond school sanctioned activities. Theory into Practice, 43(2), 102-110.

Blackburn, M. V., \& Buckley, J. F. (2005). Teaching queer-inclusive English language arts. Journal of Adolescent \& Adult Literacy, 49(3), 202-212.

Blackburn, M. V., \& Clark, C. T. (2011). Analyzing talk in a long-term literature discussion group: Ways of operating within LGBT-inclusive and queer discourses. Reading Research Quarterly, 46(3), 222-248.

Blackburn, M. V., \& McCready, L. T. (2009). Voices of queer youth in urban schools: Possibilities and limitations. Theory into Practice, 48(3), 222-230.

Bleich, D. (1989). Homophobia and sexism as popular values. Feminist Teacher, 4, 21-28.

Bonilla, L., \& Porter, J. (1990). A comparison of Latino, Black, and non-Hispanic White attitudes toward homosexuality. Hispanic Journal of Behavioral Sciences, 12(4), 437-452. 
Bontempo, D. E., \& D’Augelli, A. R. (2002). Effects of at-school victimization and sexual orientation on lesbian, gay, or bisexual youths' health risk behavior. Journal of Adolescent Health, 30, 364-374.

Cameron, L., \& Rutland, A. (2006). Extended contact through story reading in school: Reducing children's prejudice toward the disabled. Journal of Social Issues, 62(3), 469-488.

Carrera-Fernández, M., Lameiras-Fernández, M., Rodríguez-Castro, Y., \& Vallejo-Medina, P. (2013). Bullying among spanish secondary education students: The role of gender traits, sexism, and homophobia. Journal of Interpersonal Violence, 28(14), 2915-2940.

Cart, M. (1997). Honoring their stories, too: Literature for gay and lesbian teens. ALAN Review, 25(1), 40-45.

Cart, M. (2004). What a wonderful world: Notes on the evolution of GLBTQ literature for young adults. The ALAN Review, 32(2), 46-52.

Cart, M., \& Jenkins, C. A. (2006). The heart has its reasons: Young adult literature with gay/lesbian/queer content, 1969-2004 (Vol. 18). Scarecrow Press.

Caughlan, S., Juzwik, M. M., Kelly, S., Borsheim-Black, C., \& Fine, J. C. (2013). English teacher candidates developing dialogically organized instructional practices. Research in the Teaching of English, 47(3), 213-246.

Clark, C., \& Blackburn, M.V. (2009). Reading LGBT-themed literature with young people: What's possible? English Journal, 98(4), 25-32.

Corley, T. J., \& Pollack, R. H. (1996). Do changes in the stereotypic depiction of a lesbian couple affect heterosexuals' attitudes? Journal of Homosexuality, 32(2), 1-18.

Craig, W. M., \& Pepler, D. J. (1995). Peer processes in bullying and victimization: An observational study. Exceptionality Education Canada, 5, 81-95.

Craig, W. M., \& Pepler, D. J. (1997). Observations of bullying and victimization in the school yard. Canadian Journal of School Psychology, 13, 41-59.

Curwood, J. S., Schliesman, M., \& Horning, K. T. (2009). Fight for your right: Censorship, selection, and LGBTQ literature. English Journal, 37-43.

Daniels, C. B., \& Scully, S. (1992). Pity, fear, and catharsis in Aristotle's Poetics. Nous, 26(2), 204217. 
Douglas, N., Warwick, I., Kemp, S., Whitty, G., \& Aggleton, P. (1999). Homophobic bullying in secondary schools in England and Wales - teachers' experiences. Health Education, 99, $53-60$.

Durell, M., Chiong, C., \& Battle, J. (2007). Race, gender expectations, and homophobia: a quantitative exploration. Race, Gender \& Class, 299-317.

Entin, G. (Director). (2013). Geography club [Motion picture]. Huffington Pictures.

Eskridge Jr, W. N. (2000). No promo homo: The sedimentation of antigay discourse and the channeling effect of judicial review. NYUL Review, 75, 1327.

Espelage, D. L., Basile, K. C., \& Hamburger, M. E. (2011). Bullying perpetration and subsequent sexual violence perpetration among middle school students. Journal of Adolescent Health, 50(1), 60-65.

Espelage, D. L., Holt, M. K., \& Henkel, R. R. (2003). Examination of peer-group contextual effects on aggression during early adolescence. Child Development, 74(1), 205-220.

Finken, L. L. (2002). The impact of a human sexuality course on anti-gay prejudice: The challenge of reaching male students. Journal of Psychology \& Human Sexuality, 14(1), 37-46.

Fisher, F. L. (1968). Influences of reading and discussion on the attitudes of fifth graders toward American Indians. The Journal of Educational Research, 130-134.

Gallo, D. (2004). Bold books for innovative teaching: The boldest books. English Journal, 93(4), 126-130.

Geasler, M.J., Croteau, J.M., Heineman, C.J., \& Edlund, C.J. (1995). A qualitative study of students' expressions of change after attending panel presentations by lesbian, gay, and bisexual speakers. Journal of College Student Development, 36, 483-492.

Geller, W.W. (1991). Lesbian and gay topics: Awakening a campus. Journal of College Student Development, 32, 91-92.

GLSEN. (2012). "No Promo Homo" Laws. Retrieved November 10, 2014, from http://glsen.org/learn/policy/issues/nopromohomo.

Godenzi, A., \& De Puy, J. (2001). Overcoming boundaries: A cross-cultural inventory of primary prevention programs against wife abuse and child abuse. Journal of Primary Prevention, 21(4), 455.

Grack, C., \& Richman, C. L. (1996). Reducing general and specific heterosexism through cooperative contact. Journal of Psychology \& Human Sexuality, 8(4), 59-68. 
Green, S., Dixon, P., \& Gold-Neil, V. (1993). The effects of a gay/lesbian panel discussion on college student attitudes toward gay men, lesbians, and persons with AIDS. Journal of Sex Education and Therapy, 19(1), 47-63.

Haertling-Thein, A. (2013). Language arts teachers' resistance to teaching LGBT literature and issues. Language Arts, 90(3), 169-180.

Hamilton, G. (1998). ReadingJack. English Education, 30(1), 24-43.

Hansen, G. L. (1982). Measuring prejudice against homosexuality (homosexism) among college students: A new scale. The Journal of Social Psychology, 117(2), 233-236.

Hartinger, B. (2009). Geography club. NY: Harper Collins.

Hartinger, B. (2016). My books. Brent's Brain. Retrieved February 28, 2016, from http://brenthartinger.com/the-russel-middlebrook-books-2/

Hayn, J., \& Hazlett, L. (2008). Connecting LGBTQ to others through problem novels: When a LGBTQ is NOT the main character. The ALAN Review, 36(1), 66-72.

Hegarty, P. (2002). 'It's not a choice, it's the way we're built': symbolic beliefs about sexual orientation in the US and Britain. Journal of Community \& Applied Social Psychology, 12(3), 153-166.

Hegarty, P., \& Pratto, F. (2001). Sexual orientation beliefs: their relationship to anti-gay attitudes and biological determinist arguments. Journal of Homosexuality, 41(1), 121-135.

Herek, G. M. (1984). Attitudes toward lesbians and gay men: A factor-analytic study. Journal of Homosexuality, 10(1-2), 39-51.

Herek, G.M. (2000). Sexual prejudice and gender: Do heterosexuals' attitudes toward lesbians and gay men differ? Journal of Social Issues, 56(2), 251-266.

Herek, G. M. (1984). Attitudes toward lesbians and gay men: A factor-analytic study. Journal of Homosexuality, 10(1-2), 39-51.

Herek, G. M., \& Capitanio, J. P. (1995). Black heterosexuals' attitudes toward lesbians and gay men in the United States. Journal of Sex Research, 32, 95-105.

Hilton, N. Z. (2000). The role of attitudes and awareness in anti-violence education. Journal of Aggression, Maltreatment \& Trauma, 3(1), 221-238.

Hilton, N. Z., Harris, G. T., Rice, M. E., Krans, T. S., \& Lavigne, S. E. (1998). Antiviolence education in high schools: Implementation and evaluation. Journal of Interpersonal Violence, 13, 726-742. 
Hoffman, M. (1993). Teaching "Torch Song": Gay literature in the classroom. English Journal, 82, (5), 55-58.

Hudson, W. W., \& Ricketts, W. A. (1980). A strategy for the measurement of homophobia. Journal of homosexuality, 5(4), 357-372.

Hughes-Hassell, S., Overberg, E., \& Harris, S. (2013). Lesbian, gay, bisexual, transgender, and questioning (LGBTQ)-themed literature for teens: Are school libraries providing adequate collections? School Library Research, 16.

Jaffe, P. G., Suderman, M., Reitzel, D., \& Killip, S.M. (1992). An evaluation of a secondary school primary prevention program on violence in intimate relationships. Violence and Victims, 7, 129-146.

Juzwik, M. M., Borsheim-Black, C., Caughlan, S., \& Heintz, A. (2013). Inspiring dialogue: Talking to learn in the English classroom. New York, NY: Teachers College Press.

Kann, L., Kinchen, S., Shanklin, S.L., Flint, K., Hawkins, J., Harris, W.A.,...Zaza, S. (2013). Youth Risk Behavior Surveillance - United States, 2013. Centers for Disease Control and Prevention Surveillance Summaries, 63(4). Retrieved from http://www.cdc.gov/mmwr/pdf/ss/ss6304.pdf.

Kaywell, J. F. (1993). Adolescents at risk: A guide to fiction and nonfiction for young adults, parents, and professionals. Westport, CT: Greenwood Press.

Kaywell, J. F. (2004). Using literature to help troubled teenagers cope with abuse issues. Westport, CT: Greenwood Press.

Kline, P. (1999). The handbook of psychological testing. London: Routledge.

Knotts, G., \& Gregorio, D. (2011). Confronting homophobia at school: High school students and the Gay Men's Chorus of Los Angeles. Journal of LGBT Youth, 8(1), 66-83.

Koeller, S. (1977). The effect of listening to excerpts from children's stories about MexicanAmericans on the attitudes of sixth graders. The Journal of Educational Research, 70, (6), 329-334. 
Kosciw, J. G., Greytak, E. A., Bartkiewicz, M. J., Boesen, M. J., \& Palmer, N. A. (2012). The 2011 national school climate survey: The experiences of lesbian, gay, bisexual and transgender youth in our nation's schools. Gay, Lesbian and Straight Education Network (GLSEN). Retrieved September 13, 2014, from http://glsen.org/sites/default/files/2011\%20National\%20School\%20Climate\%20Survey\%20F ull\%20Report.pdf.

Lance, L.M. (1987). The effects of interaction with gay persons on attitudes toward homosexuality. Human Relations, 40(6), 329-336.

Letcher, M. (2009). Off the shelves: Celebrating love in all shades: YA books with LGBTQ themes. English Journal, 123-126.

Levitt, E. E., \& Klassen, Jr, A. D. (1976). Public attitudes toward homosexuality: Part of the 1970 national survey by the Institute for Sex Research. Journal of Homosexuality, 1(1), 29-43.

Lewis, G. B. (2003). Black-white differences in attitudes toward homosexuality and gay rights. Public Opinion Quarterly, 67(1), 59-78.

Liebkind, K \& Mcalister, A. (1999). Extended contact through peer modeling to promote tolerance in Finland. European Journal of Social Psychology 29, 765-780.

Lindbloom, K. (Ed.). (2009). Sexual identity and gender variance [Special issue]. English Journal, 98(4).

Lopez-Ropero, L. (2012). 'You are a Flaw in the Pattern': Difference, autonomy and bullying in YA fiction. Children's Literature in Education, 43(2), 145-157.

Maas, C. J., \& Hox, J. J. (2004). Robustness issues in multilevel regression analysis. Statistica Neerlandica, 58(2), 127-137.

Maas, C. J., \& Hox, J. J. (2005). Sufficient sample sizes for multilevel modeling. Methodology, 1(3), 86-92.

Malo-Juvera, V. (2014). Speak: The effect of literary instruction on adolescents' rape myth acceptance. Research in the Teaching of English, 48(4), 404-427.

Malo-Juvera, V. (2015). A mixed methods study of pre-service teachers' attitudes toward LGBTQ themed literature. Study and Scrutiny: Research on Young Adult Literature, 1(1), 1-45.

Malo-Juvera, V. \& Spears-Bunton, L. (2015). A qualitative analysis of high school students' engagement with poetry and social justice. Journal of Language and Literacy Education, 11(2), 1-22. 
Mar, R. A., Oatley, K., Hirsh, J., de la Paz, J., \& Peterson, J. B. (2006). Bookworm versus nerds: Exposure to fiction versus non-fiction, divergent associations with personality, ability, and achievement. Journal of Research in Personality, 40, 694-712.

Mar, R. A., Oatley, K., \& Peterson, J. B. (2009). Exploring the link between reading fiction and empathy: Ruling out individual differences and examining outcomes. Communications, 34(4), 407-428.

Matusov, E. (2004). Guest editor's introduction: Bakhtin's dialogic pedagogy. Journal of Russian \& East European Psychology, 42(6), 3-11.

Meyer, E. (2008) Gendered harassment in secondary schools: Understanding teachers' (non)interventions. Gender and Education, 20(6), 555-570.

Miller, sj. (2014). Moving an anti-bullying stance into schools: Supporting the identities of transgender and gender variant youth. In A. Ibrahim (Ed.), Critical studies youth reader (pp. 161-171). New York, NY: Peter Lang.

Miller, sj, \& Slifkin, J. M. (2010). Similar literary quality": Demystifying the AP English literature and composition open question. The ALAN Review, 37(2), 6-16.

Mitchell, M. (2009). When consciousness dawns: Confronting homophobia with Turkish high school students. English.Journal, 98 (4), 67-72.

Myers, W. D. (1999). Monster. New York, NY: HarperCollins.

Nansel, T. R., Overpeck, M., Pilla, R. S., Ruan, W. J., Simons-Morton, B., \& Scheidt, P. (2001). Bullying behaviors among US youth: Prevalence and association with psychosocial adjustment. JAMA, 285(16), 2094-2100.

Norton, T. L., \& Vare, J. W. (2004). Literature for today's gay and lesbian teens: Subverting the culture of silence. English Journal, 65-69.

Nussbaum, M. C. (1990). Love's knowledge: Essays on philosophy and literature. New York: Oxford.

Nystrand, M. (with Gamoran, A., Kachur, R., \& Prendergast, C.) (1997). Opening dialogue: Understanding the dynamics of language and learning in the English classroom. New York: Teachers College Press.

Nystrand, M., \& Gamoran, A. (1991). Instructional discourse, student engagement, and literature achievement. Research in the Teaching of English, 25, 261-290. 
Olweus, D. (1993). Victimization by peers: Antecedents and long-term outcomes. In K.H. Rubin, \& J.B. Asendorpf (Eds.), Social withdrawal, inhibition, and shyness in childhood, (pp. 315341). New York, NY: Taylor \& Francis.

Owens, R.E. (1998). Queer kids: The challenges and promises for lesbian, gay, and bisexual youth. New York: Harrington Park Press.

Pagtolun-an, I. \& Clair, J. (1986). An experimental study of attitudes towards homosexuals. Deviant Behavior, 7, 121-135.

Pongratz, R. (2005). The identification and analysis of latent constructs in the measurement of homophobia. Dissertation Abstracts International, 66 (06-B). (UMI No. 3178268)

Prati, G. (2012). Development and psychometric properties of the homophobic bullying scale. Educational and Psychological Measurement, 72(4), 649 - 664.

Price, J. H. (1982). High school students' attitudes toward homosexuality. Journal of School Health, 52, 469-474.

Raja, S., \& Stokes, J. P. (1998). Assessing attitudes toward lesbians and gay men: The Modern Homophobia Scale. International Journal of Sexuality and Gender Studies, 3(2), 113-134.

Rivers, I. (1995). The victimization of gay teenagers in schools: Homophobia in education. Pastoral Care in Education, 13(1), 35-41.

Rivers, I. (2011). Homophobic bullying: Research and theoretical perspectives. New York: Oxford University Press.

Robin, L., Brener, N. D., Donahue, S. F., Hack, T., Hale, K., \& Goodenow, C. (2002). Associations between health risk behaviors and opposite-, same-, and both-sex sexual partners in representative samples of Vermont and Massachusetts high school students. Archives of pediatrics \& adolescent medicine, 156(4), 349-355.

Rotheram-Borus, M. J., Hunter, J., \& Rosario, M. (1994). Suicidal behavior and gay-related stress among gay and bisexual male adolescents. Journal of Adolescent Research, 9(4), 498-508.

Rosenblatt, L. M. (1978). The reader, the text, the poem: The transactional theory of the literary work. Carbondale, IL: Southern Illinois University.

Rosenblatt, L. M. (1995). Literature as exploration. New York: Modern Language Association of America. 
Salmivalli, C., Lagerspetz, K., Bjorkqvist, K., \& Kaukiainen, A. (1996). Bullying as a group process; Participant roles and their relations to social status within the group. Aggressive Behavior, $22,1-15$.

Schall, J., \& Kauffmann, G. (2003). Exploring literature with gay and lesbian characters in the elementary school. Journal of Children's Literature, 29(1), 36-45.

Sieben, N., \& Wallowitz, L. (2009). "Watch what you teach": A first-year teacher refuses to play it safe. English Journal, 98(4), 44-49.

Smith, P. K., Kupferberg, A., Mora-Merchan, J. A., Samara, M., Bosley, S., \& Osborn, R. (2012). A content analysis of school anti-bullying policies: A follow-up after six years. Educational psychology in practice, 28(1), 47-70.

Smith, P., \& Welchans, S. (2000). Peer education: Does focusing on male responsibility change sexual assault attitudes? Violence Against Women, 6, 1255-1268.

Stansfield, J., \& Bunce, L. (2014). The relationship between empathy and reading fiction: Separate roles for cognitive and affective components. Journal of European Psychology Students, 5(3), 9-18.

Steinbeck, J. (1937). Of mice and men. New York: Covici-Friede.

Swearer, S. M., Espelage, D. L., Vaillancourt, T., \& Hymel, S. (2010). What can be done about school bullying? Linking research to educational practice. Educational Researcher, 39(1), $38-47$.

Swearer, S. M., Turner, R. K., Givens, J. E., \& Pollack, W. S. (2008). "You're So Gay!": Do Different Forms of Bullying Matter for Adolescent Males?. School Psychology Review, 37(2), 160.

Szalacha, L. A. (2003). Safer sexual diversity climates: Lessons learned from an evaluation of Massachusetts safe schools program for gay and lesbian students. American Journal of Education, 110(1), 58-88.

Ttofi, M. M., \& Farrington, D. P. (2011). Effectiveness of school-based programs to reduce bullying: A systematic and meta-analytic review. Journal of Experimental Criminology, 7(1), 27-56.

Van de Ven, P. (1995). Effects on high school students of a teaching module for reducing homophobia. Basic and Applied Social Psychology, 17, (1 \& 2), 153-172. 
Van de Ven, P., Bornholt, L., \& Bailey, M. (1996). Measuring cognitive, affective, and behavioral components of homophobic reaction. Archives of Sexual Behavior, 25, (2), 155-179.

Waldner, L. K., Sikka, A., \& Baig, S. (1999). Ethnicity and sex differences in university students' knowledge of AIDS, fear of AIDS, and homophobia. Journal of homosexuality, 37(3), 117 133.

Waterman, A.D., Garfield, L.D., \& Hoy, S.D. (2001). From curiosity to care: Heterosexual student interest in sexual diversity courses. Teaching of Psychology, 28(1), 21-26.

Wells, J.W. (1991). What makes a difference? Various teaching strategies to reduce homophobia in university students. Annals of Sex Research, 4, 229-238.

Wright, L.W., Jr., Adams, H.E., \& Bernat, J. (1999). Development and validation of the homophobia scale. Journal of Psychotherapy and Behavioral Assessment, 21, 337-347.

Zack, J. J., Mannheim, A., \& Alfano, M. (2010). "I didn't know what to say...": Four archetypal responses to homophobic rhetoric in the classroom. High SchoolJournal, 93(3), 98-110.

Zanitsch, J. (2009). Playing in the margins: Process drama as a prereading strategy with LGBT YA literature. English Journal, 85-91.

VICTOR MALO-JUVERA is an assistant professor of English education in the Department of English at the University of North Carolina Wilmington. His research focuses on how using young adult literature and culturally responsive instruction in classrooms affects students. His previous work has been published in Research in the Teaching of English, Teachers College Record, Journal of Language and Literacy Education, Study and Scrutiny: Research in Young Adult Literature, and SIGNAL Journal. He can be reached at malov@uncw.edu. 